\title{
Aukin ferðamennska
}

\section{- áskorun í heilbrigðispjónustu}

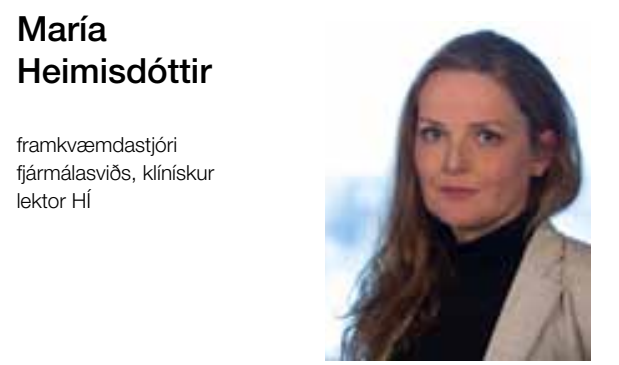

mariahei@landspitali.is

Matareitrun í skemmtiferðaskipi, tugir eldri borgara purfa vökvagjöf og aðhlynningu. Ungur franskur ferðamaður í geðrofi, parf heimfylgd. Andlát erlends ferðamanns eftir bílveltu á íslenskum malarvegi. Allt eru petta dæmi um áhrif fjölgunar erlendra ferðamanna á eftirspurn og kröfur til heilbrigðispjónustu.

Landspítalinn hefur ekki farið varhluta af pessari próun. Árið 2010 leituðu alls 2167 ósjúkratryggðir til dag- og göngudeilda spítalans, par á meðal bráðamóttöku, en árið 2014 hafði peim fjölgað um 44\%, voru 3122. Í flokk ósjúkratryggðra falla ekki eingöngu erlendir ferðamenn heldur einnig til dæmis peir sem búið hafa skemur en 6 mánuði á Íslandi og njóta pví ekki tryggingaverndar, svo og sjúklingar frá Færeyjum og Grænlandi sem hingað er vísað til pjónustu. Fjölgun ósjúkratryggðra sem sækja heilbrigðispjónustu til Landspítala má að langmestu leyti rekja til fjölgunar erlendra ferðamanna.

Á sama tíma fjölgaði innlögnum pessa hóps um 19\% (úr 283 í 336). Eðli málsins samkvæmt leita langflestir erlendir ferðamenn pjónustu yfir sumarmánuðina - pegar mönnun er oft naum vegna sumarleyfa. Árið 2014 áttu 46\% af innlögnum ósjúkratryggðra sér stað á priggja mánaða tíma, júlí-september. Áhrifa aukins ferðamannafjölda gætir pví mun meira en ætla mætti af fjöldatölum eingöngu og hugsanlega pyrfti að endurskoða mönnun og annan viðbúnað yfir pau tímabil par sem álagið er mest. Petta á ekki síst við í tengslum við komur skemmtiferðaskipa sem fluttu 105.000 farpega hingað árið 2014. Dæmi eru um að farpegar komi í rútum á bráđa- móttöku frá skipshlið samkvæmt ákvörðunum skipslæknis um að vísa öllu pví sem ekki er hægt að leysa um borð til spítalans meðan skipið liggur í höfn. Flestir farpegar skemmtiferðaskipa eru eldri borgarar, með fjölpættan heilsuvanda og taka fjölda lyfja að staðaldri - og engin fyrri heilsufarsgögn eru aðgengileg. Parna geta pví verið um meiriháttar verkefni að ræða sem leysa parf á tiltölulega skömmum tíma, oft við erfiðar aðstæður.

Eins og við er að búast leita flestir ósjúkratryggðir til Landspítala vegna minniháttar óhappa eða vandamála sem ekki krefjast innlagnar. Meðal peirra sem purfa á innlögn að halda eru algengustu vandamálin, útlimabrot, liðáverkar og tognanir, botnlangabólga og kransæðasjúkdómar. Af peim sem lögðust inn árið 2014 purfti tæpur helmingur á inngripi að halda og 12\% dvöldu á gjörgæslu, að meðaltali í 11 daga. Meðallegutími í heild var 6,6 dagar.

Almennt er óhætt að segja að Landspítala hafi tekist vel að sinna pessum ört vaxandi hópi sjúklinga en honum fylgja óneitanlega ýmsar áskoranir og viðfangsefni bæði í klínískri pjónustu og hvað praktísk mál varðar. Tungumálaerfiðleikar koma kannski fyrst upp í hugann. Gagnvart sjúklingi og aðstandendum er petta leyst með aðkomu túlka ef pess er kostur en samskiptin taka óneitanlega meiri tíma og reyna meira á en ef um sameiginlegt tungumál væri að ræða. Nauðsynlegt samráð og samskipti við lækna sjúklings heima fyrir geta verið tímafrek. Skrifa parf læknabréf á ensku fyrir hvern einstakling. Ef erlendir ferðamenn uppfylla skimunarskilmerki vegna ónæmra baktería (sjúkrahúsdvöl erlendis síðastliðna 6 mánuði, blóðskilun erlendis eða endurteknar húðsýkingar) parf að taka skimsýni (til dæmis fyrir MÓSA) og hafa sjúklingana í einangrun, með tilheyrandi ópægindum, töfum og kostnaði, par til neikvæð svör liggja fyrir.

Skrá parf ýmsar upplýsingar í sambandi við tryggingamál; taka ljósrit af vegabréfi og tryggingakortum og alloft parf аð аðstoða sjúklinga og aðstandendur við heim- ferð, fylgd og jafnvel sjúkraflug. Reikningar eru gefnir út á ensku og peim fylgt sérstaklega eftir. Iðulega parf miklar bréfaskriftir og endurtekin samskipti við erlenda greiðendur (einstaklinga, tryggingafélög) áður en reikningur er greiddur.

Tekjur Landspítala af pjónustu við ósjúkratryggða hafa vaxið verulega, eða um 99\% á föstu verðlagi milli 2010 og 2014, (úr 167 m.kr. í 385 m.kr). Pá eru tekjur af samningsbundinni pjónustu við sjúklinga frá Grænlandi og Færeyjum undanskildar. Pessi hækkun helst í hendur við próun á umfangi pjónustunnar en stafar einnig af bættu verklagi við skráningu, gagnavinnslu og gerð reikninga fyrir pennan hóp sjúklinga. Pó svo pessar tekjur séu vissulega umtalsverðar og vaxandi er pjónusta við erlenda sjúklinga að meðaltali tímafrekari og kostnaðarsamari en almennt gerist, vegna peirrar umsýslu sem að ofan er lýst, og innheimta erfið og dýr.

Gera má ráð fyrir að áhrif aukinnar aðsóknar erlendra ferðamanna á starfsemi annarra heilbrigðisstofnana séu svipuð og á Landspítala. Að sjálfsögðu er pað keppikefli allra að veita sem besta pjónustu óháð pví hvaðan sjúklingurinn kemur en huga parf sérstaklega að ákveðnum páttum (samanber hér að ofan) gagnvart pessum sjúklingahópi, ekki síst ef fjölgun ferðamanna heldur áfram á sömu braut. Tryggja verður að bæði heimamenn og hinir erlendu gestir hafi áfram aðgang að góðri og öruggri pjónustu. Lykilatriði er að tryggja að pjónusta við erlenda ferðamenn standi undir sér og kalli ekki á niðurgreiðslu úr vasa skattgreiðenda. Ef vel er að málum staðið geta falist í pessu tækifæri fyrir veitendur pjónustunnar og aukið framboð á pjónustu fyrir heildina.

Increasing tourism - a challenge for health care

María Heimisdóttir MD, PhD, MBA Chief Finance and Information Executive Clinical Lecturer, Ass. Clinical Professor Landspitali - The National University Hospital of Iceland 